\title{
Chances and Challenges of Local Wisdom as a Management Model Toward Sustainable Fisheries
}

\author{
Dian Patria Keliat ${ }^{1 *}$, Amirudin Amirudin ${ }^{2}$, and Yanuar Luqman $^{3}$ \\ ${ }^{1}$ Master of Environmental Sciences, Diponegoro University, Indonesia \\ ${ }^{2}$ Department of Social Anthropology, Faculty of Humanity, Diponegoro University, Indonesia \\ ${ }^{3}$ Department of Communication Science, Faculty of Social and Political Sciences, Diponegoro \\ University, Indonesia
}

\begin{abstract}
Indonesia is rich in local wisdoms, including in fisheries management. Fisheries management by applying local wisdom is an effort to utilize fisheries resource based on traditional noble values designated to people's welfare. Research aims to collect and analyse local wisdoms related to fisheries management in Indonesia, the concepts offered, their advantages and disadvantages, as well as efforts for their conservation. Method applied in this research is literature review, main articles collected from international and national journals, and other relevant resources as supportive data. Analysis on 24 articles show that there are 3 fisheries local wisdoms which have been researched the most: Panglima Laot-Adat Laot, kewang-sasi, and awig-awig. Panglima Laot in Aceh is considered to be the one that has strong concept and more advantages as compared to others. However, violations to its customary law still take places. Noted also that researches are not exploring the perspective of the people who are regulated by related local wisdoms. Efforts to conserve local wisdoms by building the capacity and integrating their values into formal law as management model is required. Increasing violations against Panglima Laot-Adat Laot customary law, thus, suggest research to explore people's current perspective toward local wisdom.
\end{abstract}

\section{Introduction}

Cultural Cultural richness and diversity are strongly related to biodiversity; places such as Central Africa, Amazonia, and South East Asia are the most important sources for human civilization and cultural development, including natural resources management [1]. Natural resources management based on local wisdom is quite common as well in Indonesia. Local wisdom is best selected, knowledge and know-how are used as guidance for community living in certain locations to maintain their sustainability [2].

Indonesian 1945 Constitution on article 18B and several national laws also acknowledge local wisdom existence. About natural resources management, that acknowledgement can be found in Law Number 32 of 2009 on Environmental Protection and Management (article 2, 10, 63, 69, and 70), Law Number 27 of 2007 as amended by Law Number 1 of 2014 on The

\footnotetext{
* Corresponding author: diankeliat@,students.undip.ac.id
} 
Management of Coastal Area and Isles (article 61), as well as Law Number 31 of 2004 as amended by Law Number 45 of 2009 on Fisheries (article 6).

People living in coastal areas almost all over Indonesia own and practice local wisdom in managing coastal natural resources, including fisheries, which is essentially a process of controlling human livelihoods activities in the areas so that they can be performed wisely by obeying the rules of environmental sustainability. Good natural resources management, in the end, will give advantages to both people's welfare and environmental resources' sustainability [3].

However, people living in coastal areas in Indonesia are mostly living in poverty due to factors such as the previous governmental policies that are too land-oriented, low capital and production-asset ownership, and lack of competency [4]. Poverty, economic pressure, modernization, and industrialization, if not being well managed, will reach a point where those people no longer can commit to the local wisdom that prevents them from overexploiting natural resources and damaging the environment [5].

\section{Method}

This literature review aimed to collect, compare, and analyse local wisdom in Indonesia related to fisheries management to assess their potential to be further explored and developed as a model for national fisheries management. The main articles analysed in this literature review were collected from national and international journals published within the last five years (2016-2021). Journals from Jurnal Ilmiah Kelautan dan Perikanan Indonesia was the source for national articles by entering "kearifan lokal perikanan" (fisheries' local wisdoms) as keywords. At the same time, international journals searching were using Scopus and Science Direct as access points. These access points were selected by entering keywords "Indonesia fisheries local wisdom" and "Indonesia traditional fisheries management". This first step resulted in a total of 248 articles. This first batch of the article was then refined based on two criteria: related to capturing fisheries activities of local communities in Indonesia and discussing the implementation of specific customary laws or institutions regulating capture fisheries existing in researched areas. This process resulted in 24 relevant articles, 20 articles from international journals, and the rest four articles from national journals.

\section{Results}

Based on the articles analysed, ten local pearls of wisdom focused on or strongly related to fisheries management. These local wisdom are sasi, Panglima Laot, awig-awig, papadak/hoholok, Pariaman fishermen, tri hita karana, Sebong Pereh village fishermen, Jaring Halus community, tiatiki and Duano tribe.

\subsection{Sasi}

There were four types of research studying sasi as local wisdom. Based on these researches, sasi was found in Maluku and Papua [6]-[9]. This local wisdom was not exclusively fisheries traditional management. Kaya, Hutabarat, and Bambang [9] described that there were 6 different types of sasi in Kotania Bay, West Ceram, Moluccas namely sasi laut (laut:sea), sasi hutan (hutan: forest), sasi telaga raja, sasi gereja (gereja: church), sasi morekau, and sasi mangrove.

Sasi as fisheries management had specific rules found both in the sasi of Moluccas and Papua [6], [9], where they set closed and open seasons for fishing certain species, such as sea 
cucumber and pearl. This was following the word sasi, which means "ban" [7]. Halim et al. [7] further had added that sasi in the Moluccas regulates the prohibition use of destructive fishing gears.

Some strong points of sasi as fisheries management described by the researchers were its ability to evolve through times, especially in terms of rites carried out to protect the environment which used to be animistic into professional theft prevention as well as sanctions imposed to the sasi violators where it used to be social humiliation, which had changed into monetary fines [7]. In its implementation within the society, Sasi had its law enforcer called kewang [7], [9]. Kewang works autonomously [7], sasi as a customary law still effectively executed not only because the law was consistently enforced [9] but also because most people in society still believed that violation of the customary law would lead to worse punishment from God rather than just punishment they will get from kewang if ever they were caught doing infringements [7].

Challenges that sasi encounter nowadays was lacking or limited legal and formal support from the government [6]. Halim et al. [7] also stated that the first problem became even worse with the fact that sasi was currently facing organizational problems such as poor leadership and forced to adapt to changes of village administration boundaries, as well as has to survive the socio-cultural challenge where many outsiders come into their territory and do not recognize or support sasi.

Research of sasi in Sorong, West Papua and Kotania Bay only emphasize the importance of this local wisdom in anticipating the modernization and economic growth that would affect the environment, including coastal areas, as well as a higher risk of conflict among people within society [8], [9]. Other researchers [6], [7] urged that sasi must somehow formalize into a kind formal coastal area management (fisheries management rights - FMR) to be more effectively impacted to the effort of reaching sustainability in fisheries.

\section{a. Panglima Laot}

Panglima laot Panglima laot (Panglima: commander; Laot: sea) was a traditional institution found in Aceh province, which history can be traced back to the Aceh sultanate era [10]. At the beginning of the formation in the 14th century during the Samudera Pasai kingdom (the oldest Islamic kingdom in Indonesia's history), Panglima laot was sultanate's officers who were responsible for two main tasks: regulating activities related to sea (sea fishing, excise from merchant ships, wages, etc.) and mobilize people in the sake of war [11]. One of the research conducted by Abdullah, Arifin, and Tripa [12] also stated that the historical study of Panglima laot shows that his rule was based on an area called lhok or Muara (estuary). In modern times, after Indonesia, as a nation got its independence from Dutch and Japanese colonialism, the role of Panglima laot had changed as well, where at the beginning, the Indonesian government was seemingly neglected this traditional institution, even though it finally got a more robust formal-legal basis thru validation Law Number 44 of 2000 on the Implementation of Special Feature of the Special Province of Aceh. Based on this law, Panglima laot was officially declared as a state institution in Aceh Province [13]. Panglima laot in this modern era had a specific role in regulating the fishermen and fisheries activities, especially to maintain the fishermen adherence to the hukum adat laot (customary laws of the sea), to resolve disputes in connection with marine fishing, and to hold customary sea ceremonies, coordinating efforts in handling accidents at sea, and to managing other relevant social issues [14]. Besides these managerial roles, a Panglima laot also had the judicial authority to impose certain sanctions based on the customary court held by the lhok community he led [13]. Hukum adat laot, in its relation to ecological conservation, regulated three crucial aspects, namely prohibit the use of destructive fishing 
gears (bombing, poisoning, or illegal coral reefs mining), prohibit fishing of protected sea animals and plants, and prohibit the cutting of trees growing on coastal areas such as mangrove, coastal spruce, and pandanus as well as prohibit fishing on specific days such as Islamic feast days, Indonesian national day, and Fridays [12], [13].

Panglima laot as traditional institutions in Aceh has several advantages mainly related to the long history it possesses, acknowledgement from government both local and central [10][12], and adat laot that had been written down [10]. Research in Sabang (one of the cities within Aceh province administration) showed that Panglima laot's performance in coastal resource management has been effective and running well [13].

As an institution, Panglima laot showed some indicators that it has been traditional yet modern. It can be seen based on the fact that this institution has been cooperating with some national, even international institutions such as Gerakan Aceh Merdeka (Aceh's Freedom Movement) during its conflict with Indonesian authority, with the Indonesian government, and the United Nations [10]. However, this condition also potential to the occurrence of overlapping authorities with formal government officers and misuse of this institution for political interests and diverted from its original purpose as traditional fishery management.

\section{b. Awig-awig}

Awig-awig Awig-awig was a set of customary laws in environmental conservation and maintaining resources effort [15]. This local wisdom was commonly found in the West Nusa Tenggara province of Indonesia [16]-[18]. However, the terminology awig-awig is also found in Bali [19]. The difference between awig-awig in Bali compared to Lombok and West Nusa Tenggara's based on research collected in this literature review was that awig-awig in Bali focus on forest reservation regulation [19]. In contrast, awig-awig in Lombok and West Nusa Tenggara focus on regulating coastal area management [16]-[18]. Therefore, this terminology is not exclusively related to coastal/fisheries local wisdom, which makes it similar to sasi terminology.

Some aspects of fishing management that are regulated by awig-awig were prohibiting the use of destructive fishing gears, setting certain days as no-fishing days, prohibiting coral reef destruction, and fishing zoning management [16], [18]. Besides coastal management regulation, awig-awig also defines sanctions imposed on those who infringe the regulation, ranging from delicate as the most lenient to a death sentence as the most severe [18].

Efforts to optimize awig-awig for fisheries conservation purpose has been started since 1994 where officials in Tanjung Luar village, Keruak, West Nusa Tenggara tried to use awigawig as a basis to set fishing zoning for modern and semi-modern fishing boats in particular, as well as regulate fishing gear allowed to be used. However, this effort has not been successful due to lacking supportive national nor local regulation [16]. Based on research in Mertak Village, Central Lombok, by Cahyowati et al., other challenges to implement awigawig was the difference in conservation principles basis used as compared to formal Indonesian laws [3], where the principles contained in awig-awig seemed to be an effort to meet the needs of maintaining values of life of the local community and its social life. Even it was set to meet the characteristic of its local community, customary law enforcement is still a problem where it was difficult to be done [3].

Despite these problems, awig-awig researched in Central Lombok also has a strong point where it relatively had a complete set of regulations in managing coastal and fisheries sectors [3], another strong point, as per researched by Hilmawan et al. in 5 subdistricts of North Lombok district, was the fact that it still receives good perceptions and aspirations from the local society. 


\section{c. Papadak/Hoholok}

A Research for papadak/hoholok in Rote Ndau district of East Nusa Tenggara province in 2016 described that papadak (a term used in the eastern part of Rote) and hoholok (a term used in the western part of Rote) was a set of rules that pre-dated the arrival of Dutch and Portuguese, that prohibits someone from using someone else's properties without permission [15]. Other research conducted in 2018 by Oktavia, Salim, and Perdanahardja describe that papadak was originally local wisdom applied for agricultural and plantation before being implemented for managing marine conversation in Rote Ndao [20]. The principle of papadak for agricultural management was more on preventive means anticipating disputes among community members regarding land usage [20].

Application of this local wisdom was reported has been in effect for seaweed farming management, where a set of rules about seaweed farming was implemented as a revitalization of papadak in Daiama village, Rote Ndau. These rules include the prohibition of taking seaweed from others' plantations, the prohibition of catching fish in seaweed farming locations, and stipulating sanctions for the violators [15]. On its fundamental principles, the implementation of papadak is based on territory called nusak. This familiar territory differs from those regulated by the Indonesian administration. However, it may be comparable with a subdistrict led by a manoholo whose main task is to maintain the customary law [20]. Some of the written laws that marine papadak had, among others were prohibited use of destructive fishing gears such as bombs, trawls, and poison, prohibit cut of mangrove trees, prohibit throwing garbage into the sea, prohibit mine of the sand sea using heavy equipment, including sanctions for violators [20].

Strong points of papadak as local wisdom is in a term that it has written set of rules [15], [20]. Marine papadak is also reported to be fully supported by the local society. Their aspirations were generated recently, and rules are set based on community agreement with government supervision [20]. However, the main challenge for this local wisdom in its implementation was the absence of local even national law that regulate customary rights of marine management area [20].

\section{d. Pariaman Fishermen}

There were relatively few related to Pariaman (a district in West Sumatera Province) fishermen's local wisdom. Pariaman district has four marine protected areas (MPA), namely Ujung Island, Tangah Island, Angso Island, and Kasiak Island [21]. The only research collected in this literature review and then further analysed was conducted by Zamzami et al. in 2020. Pariaman's local fishermen are reported implementing a set of rules in fisheries resources conservation purpose, namely prohibits the use of destructive fishing gears, prohibit catch of turtle, prohibit throw garbage into the sea, and limitation of mangrove trees utilisation [21]. The awareness to conserve marine environment only came up recently within coastal society in Pariaman. Due to the shifting in their primary livelihood from land oriented into marine-oriented, this is also the vital point that it carries. This local wisdom, unfortunately, is only acknowledged by small scale fisheries in the area [21].

\section{e. Tri Hita Karana}

Tri Hita Karana, as local wisdom, was not exclusively purposed for fisheries or marine conservation; it was more on environmental conservation effort, in general, that may, subject 
to the needs, covers agricultural, forestry, and fisheries [22]. As described by Wanadjaja and Saputra, the basic principles of this local wisdom were to reach harmony among humans, between humans and the environment, and between humans and their creator [22]. The strong point of this local wisdom was its potential to improve the welfare of Balinese small scale fishers. At the same time, the obstacle in implementing tri hita karana was that fisheries in Bali are dominated by industrial-scale fishing armada that are relatively less concerned with this local wisdom [22].

\section{f. SebongPereh Village Fishermen}

Sebong Pereh village is located in Bintan Island, Riau Islands Province. Local wisdom in this village was specifically purposed to conserve seahorse (Hippocampus, spp) within the area of Sebong Pereh village. Seahorse was a highly economy valued commodity, thus making it more vulnerable to extinction due to overexploitation [23]. The research conducted in 2017 by Ulfah, Afrizal, and Pratomo reported that local wisdom in SebongPereh village emerged from community consciousness regarding the importance of seahorse sustainability as resources, which led to the establishment of local marine protected areas for seahorse conservation [23]. Implementation of this marine protected area was, however still needs more attention, especially in terms of community commitment and controlling [23].

\section{g. Jaring Halus Village}

Local wisdom that existed in Jaring Halus village, Langkat District, North Sumatera Province, actually consists of guidance for fishers on determining the best season for fishing using a Hijriyah calendar as a basis and advice to maintain mangrove ecosystem within the coastal areas [24]. Research on 2019 by Aulia also mentioned that local wisdom in Jaring Halus village was more on fishermen welfare and safety during fishing activities [24]. Therefore it had limited marine or fisheries conservation values.

\section{h. Tiatiki}

Similar to sasi, as a fisheries-related local wisdom tiatiki also basically regulate open and closed fishing areas for specific fish species, both demersal and pelagic, that were existed in Depapre bay, Jayapura City, Papua [25]. This local wisdom emerged from local community awareness on the needs of the marine, especially fishery resources conservation, which is considered the decisive point. On the other hand, this local wisdom needs more attention from the local authority to be more effectively implemented and contribute to fishery conservation efforts.

\section{i. Duano Tribe}

Suku Duano (suku: tribe) lives in the coastal area of Jambi Province and is considered a branch of larger Suku Laut (suku: tribe, laut: sea) lived in Riau and Jambi coastal areas. Suku Laut had a long history that can be traced to the Srivijaya Kingdom era [26]. Suku Duano, like its larger tribe group, was well known for their sea expertise; however, in this modern time, some of them has started to leave their old ways of life where they already moved to a land settlement instead of living on the sea [26].

Some marine conservation values are still implemented for those Suku Duano members who remained on the sea to make a living. Those values, among others, were avoiding excessive use of marine resources, considering the sea as a sacred place, and prohibiting 
fishing activities on Friday [26]. Another important note of local wisdom from Suku Duano that it was also had a doctrine to be not dependent solely on fishery resources during the difficult season and urged to look for an alternative as an income source [26]. However, the local wisdom of Suku Duano became less and less practised due to the changing the way of life of the tribe member and blending with other tribes in Jambi.

\section{Discussion}

Based on specified and relevant articles collected, there are three local pearls of wisdom researched the most: sasi, Panglima Laot, and awig-awig. Sasi, in particular, was researched in 4 different articles [6]-[9], three articles based on research of sasi in Molucca, while another research was based on sasi implementation in Papua [9]. Articles focusing on Acehnese's Panglima Laot and adat laot were found in as many as five articles [10]-[14]. In comparison, awig-awig regarding marine and fisheries conservation researches results were found in 4 articles. All articles of awig-awig result from researches carried out in West Nusa Tenggara province's districts [3], [16]-[18].

Other local wisdom noted in this literature review, except papadak/hoholok, are relatively less researched. They are only found in 1 article each, so it is relatively more challenging to dig more insight except what has been described in the results section. As for papadak/hoholok of Rote Ndau district of East Nusa Tenggara is found in 2 types of research articles published [15], [20]. Papadak/hoholok seemed to have the potential to be solid local wisdom as it was generated just recently during the relatively modern time. Local society's enthusiasm for marine and fishery conservation has motivated them to adopt their pre-existing local land or agricultural-oriented wisdom for marine and fisheries management [20]. Other factors that should be supportive are the existence of written customary law, including the customary law enforcer called manoholo, who is also a part of a customary organization designed for papadak/hoholok. The existence of organizational structure and written customary law are some of the most critical aspects. However, this particular marine papadak/hoholok local wisdom is relatively new and may face a challenge in its implementation, especially in adjusting the community's mindset from land-oriented to marine-oriented.

Another note that leads to the impression that sasi, Panglima laot, and awig-awig are the most "popular" local wisdom is that at least combination any 2 out of these three local pearls of wisdom frequently referred to as fisheries local pearls of wisdom within an article collected. This event is found in 8 articles [3], [7], [10], [17], [18], [21], [27], [28]. Some factors probably cause the popularity of these three local pearls of wisdom. However, the main factor should be their long history and existence within their local society, which remains strong and effective. Another characteristic that is similar among these three local pearls of wisdom is the existence of organizational structure. Sasi and awig-awig were not specifically described to have a clear organizational structure based on relevant articles analyzed. The existence of kewang as a customary law enforcer for sasi and the existence of levels of punishment severity in awig-awig system, however, indicate a certain mechanism, especially in customary law enforcement, which normally will not be done individually according to common practices in Indonesian culture. Thus, it absolutely will need organizational management, even in the simplest form, for the implementation.

Panglima laot, on the other hand, has a clear and written organizational structure. Based on the first Panglima Laot conference held in 2000, the highest position is the Panglima Laot Province at the provincial level. At the second level is Panglima Laot Kabupaten, and at third level is Panglima Laot Lhok. Each level has its organizational structure that consists of a chief, advisory board, treasurer, and secretary [10]. At this conference, hukom adat laot (hukom: law, adat: customary, laot: sea) was also arranged and implemented [29]. 
Each Panglima Laot (at a lower level) is allowed to arrange their hukom adat laot to meet the specific condition in their area even though so far there are only 2 Panglima Laot recorded to have this lower-level law, namely Pidie District and Susoh Subdistrict [30].

Other findings regarding Panglima Laot are that it manages an endowment resulting from their significant contribution in apprehending 57 illegal fishing boats from Thailand in 2001. The fund collected from the auction of those boats amounts to 12 billion Indonesia rupiah is then used as an endowment for Acehnese fishermen children's scholarship [29].

According to these facts, Panglima laot as a customary institution in the fishery is considered a complete package. Support from national law, namely Law Number 32 of 2009 on Environmental Protection and Management (article 2, 10, 63, 69, and 70), Law Number 27 of 2007 as amended by Law Number 1 of 2014 on The Management of Coastal Area and Isles (article 61), as well as Law Number 31 of 2004 as amended by Law Number 45 of 2009 on Fisheries (article 6) are all acknowledging local wisdom in the effort of environmental and/or fishery conservation. However, sasi and awig-awig have less support in this aspect as compared to Panglima Laot's since Aceh has specific national law and qanun (local regulation) used as the basis for its implementation, namely Law Number 11 of 2006 on Aceh Government (it makes Aceh administration is regulated separately with other provinces in Indonesia that are regulated under Law Number 23 of 2014 on Local Government), and Qanun Number 9 of 2008 on Management of Customs in Aceh as well as Qanun Number 10 of 2008 on Customary Institutions. The effort to provide proper law support for awigawig in 1994 from Mertak Village officials in West Nusa Tenggara as described in the results of this article had yet been successful and no report, if there has been any latest effort, carried out [16].

Panglima Laot, with its adat laot seemed to be the most capable in managing the fishery and coastal areas. This customary institution even becomes a model of early fishery resources surveillance on a community basis called Pokmaswas a short term for Kelompok Masyarakat Pengawas (kelompok: group, masyarakat: community, pengawas: comptroller) initiated by the Ministry of Marine and Fisheries Affairs for their successful effort in handling illegal fishing boats from Thailand that were apprehended operating on Aceh's waters in 2001[29]. However, the government has not utilized the best potential that Panglima laot and adat laot have as an institution. Resources utilized the most from this institution are more on their extensive existence that covers almost all coastal areas in Aceh, making them a good "eyes and ears" extension for limited government officers in charge. Conservation enthusiasm reflected in the noble values, conventional trial system, and appreciation to the Panglima laot at lhok level is some essential things the government needs to pay more attention to.

Challenges are how to ideally incorporate these local wisdom values into formal law and develop local wisdom itself to cope with the dynamics of environmental issues. For the case of Panglima laot, for instance, the complete regulation sometimes, on the contrary, may create a conflict between adjacent lhok. For instance, a lhok (A) prohibits using a specific type of fishnet, while another lhok (B) adjacent allows the usage of the same type of fishnet. Since the sea, in principle, is open access resources [31]. Thus boundaries between lhok are not easy to distinguish. When fishers of lhok B fishing use prohibited fishnet without knowing that he is already in lhok A territory, the conflict may happen. This kind of issue needs to be addressed well in perfecting the local wisdom, especially in a framework of developing society knowledge on scientific of fisheries issues and capacity building for Panglima laot and further arranging an anticipative formal law for even a bigger purpose, sustainability in fisheries.

All local wisdom has excellent social capital generated from local society awareness on the importance of conserving the environment and further-reaching sustainability. It can be coastal, marine, or land environment, wherever they live [32]. Unlike scientific knowledge based on researches and empirical evidence, local wisdom is almost always considered 
irrational. Western advanced science and technology and adaptation of their scientific approach worldwide had also created this stigma, which has been why local wisdom has become marginal [33]. Only for the last few decades, it is finally realized that the application of modern science adapted from western was one of the main factors contributing to massive environmental degradation such as deforestation, over-fishing, and pollution. Local wisdom, on the other hand, has been much more successful in serving the environment well, even though values adhered to and carried out by implementer society was merely to preserve their custom way of life and considered unscientific since the concept of local wisdom was taking what was needed instead of maximizing profit [34].

However, local wisdom also, due to some factors, such as modernization, values and rules stipulated in that local wisdom may be losing adherence from its society [33]. For instance is destructive fishing (bombing) is a fisheries crime case that is occurring in Aceh that can be seen from reports in several online news regarding fish bombing practices [35], [36]. Destructive fishing occurs in many places all over Indonesia, even in marine conservation areas [37]. Economic pressure and a quick and easy way to get the fish probably have made these small-scale fishers neglect the local wisdom and even national law. Dealing with poverty in globalization, industrialization, and modernization was another tough challenge to conserve local wisdom [33].

One of the efforts to sustain local wisdom is to integrate it into formal law. In terms of the coastal area and fishery management, where people living in this area have their characteristics, generally described as hard tempered, firm, and outspoken [38], it will also help reduce potential conflict after the law is implemented. One of the keys for successful environmental management is to involve stakeholders in arranging, implementing, and enforcing the law used as its management basis [39]. Research in French Polynesia showed that efforts in conserving overexploited bonefish thru scientific research and education centre run by local communities had successfully revitalized rahui, a pearl of local fishery wisdom that has been inactive for years as a management model [40]. The keyword was that the local society itself initiated it. Another research also showed that indigenous people living in a coastal area, so far, were less represented for their interest and rights to live in good welfare as custodians of highly valued fish commodities, even though their rights are internationally recognized [41]. Therefore, proper support and acknowledgement of customary institutions existing in a coastal area such as Panglima Laot, sasi, or awig-awig will also give better access for indigenous people in the coastal area for their right to get the best possible benefits from the place they have been living in.

Another reason the importance of government's acknowledgement and incorporating customary law as well as indigenous people rights into formal law is that it is one of the efforts to gain community's trust back, especially in law aspect, for creating good environmental governance, aside from efforts on other aspects namely political, economics, as well as social aspect [42].

\section{Conclusion}

Local Local wisdom can be an excellent chance to manage fishery resources to its sustainability and coastal area community welfare. The originality of values used and compatibility with the local social customs are good social capital for good adherence. Therefore, using local wisdom as a basis for formal regulation regarding fisheries and coastal management will bring more advantages such as less rejection from the community, voluntary supervision in law enforcement, and ease of implementation. This is also an effort to conserve the local wisdom itself, which can be done by involving stakeholders in the area for its management. 
Regarding the level of adherence to the local wisdom that consistently found decreasing as reported on sasi [7] and awig-awig [3] implementation, and even to Panglima Laot and adat laot implementation in Aceh, it will need further research since research results collected in this literature review mainly were using local wisdom' point of view and less exploring local society's point of view especially what difficulties and challenges they have to deal by the existence and implementation of this local wisdom.

Unfortunately, the various local wisdom found all over Indonesia, whether agricultural, fisheries or even social related, has yet been well documented. Thus, in fisheries management, the challenge is how to manage efforts to document, write down the values, perform scientific research to selected local wisdom about fisheries management, arrange supportive formal law base, execute, control, and finally evaluate the implementation. This is an essential process for both conservation efforts of the local wisdom themselves and reaching sustainable development.

\section{References}

1. N. Wijana, Ilmu Lingkungan, 2nd ed. Yogyakarta: Graha Ilmu, (2014)

2. A. Samekto, Hukum Lingkungan, 1st ed. Tangerang: Penerbit Universitas Terbuka, (2019)

3. C. Cahyowati, G. Asmara, A. Arba, and A. Zainuri, "Local Wisdom Values-Based Coastal Natural Resources Management," in Proceedings of the International Conference on Business Law and Local Wisdom in Tourism (ICBLT 2018), 2018, vol. 282, no. Icblt, pp. 221-224.

4. R. Rahadian, M. Firdaus, and A. Ramadhan, "Struktur Pendapatan Perikanan Tangkap Keluarga Nelayan dan Implikasinya: Analisis Data Panel Kelautan dan Perikanan Nasional," J. Sos. Ekon. Kelaut. dan Perikan., vol. 11, no. 2, p. 237, (2016)

5. M. R. Siombo, Dasar-Dasar Hukum Lingkungan dan Kearifan Lokal Masyarakat. Jakarta: Penerbit Universitas Katolik Indonesia Atma Jaya, (2015)

6. A. Halim, B. Wiryawan, N. R. Loneragan, A. Hordyk, D. S. Adhuri, and L. Adrianto, "Konsep Hak Pengelolaan Perikanan Sebagai Alat Pengelolaan Perikanan Berkelanjutan di Indonesia," J. Kebijak. Perikan. Indones., vol. 9, no. 1, pp. 11-20, (2017).

7. A. Halim et al., "Transforming traditional management into contemporary territorialbased fisheries management rights for small-scale fisheries in Indonesia," Mar. Policy, vol. 116, no. March, p. 103923, (2020)

8. Z. Anna, "Sustainable Production Management and Consumption of Village, Sorong District, West Papua," "MARINA” Sos. Ekon. Kelaut. dan Perikan., vol. 4, no. 1, pp. 15-21, (2018).

9. I. R. G. Kaya, J. Hutabarat, and A. N. Bambang, "Sasi': A New Path to Sustain Seaweed Farming From UpStream to Down-Stream in Kotania Bay, Molucass," Int. J. Soc. Ecol. Sustain. Dev., vol. 9, no. 2, pp. 28-36, (2018)

10. K. Bustamam-Ahmad, "A study of Panglima La'Ōt: An 'Adat institution in Aceh," AlJami'ah, vol. 55, no. 1, pp. 155-188, (2017)

11. M. P. Utama, Y. Rochwulaningsih, S. T. Sulistiyono, and Mujiburrahman, "Transformation of Panglima Laot in Aceh: From Punggawa to Customary Institution," E3S Web Conf., vol. 202, (2020)

12. M. A. Abdullah, A. Arifin, and S. Tripa, " Panglima Laot: His Legacy and Role in Conserving Marine Resources in Aceh, Indonesia ," SHS Web Conf., vol. 45, p. 06003, 
(2018)

13. Mustaqim and A. Reni, "Analysis of institutional panglima laot as community based coastal resource management," Int. J. Sci. Technol. Res., vol. 7, no. 5, pp. 203-206, (2018).

14. A. Rahmah, S. Salmarika, and E. Miswar, "The role of panglima laot towards fisheries management based on ecosystem approach in Banda Aceh City," IOP Conf. Ser. Earth Environ. Sci., vol. 674, no. 1, (2021)

15. A. Satria, N. H. Muthohharoh, R. A. Suncoko, and I. Muflikhati, "Seaweed farming, property rights, and inclusive development in coastal areas," Ocean Coast. Manag., vol. 150, pp. 12-23, (2017)

16. A. Hidayat and P. Safitri, "Pengembangan Komoditas Rumput Laut Nusa Tenggara Barat Dengan Model Hexagon Untuk Pembangunan Ekonomi Lokal," J. Kebijak. Sos. Ekon. Kelaut. dan Perikan., vol. 9, no. 1, p. 45, (2019)

17. A. Wahyono and M. Illiyani, "The Concept of the Right to Management of Coastal Communities in the Regional Autonomy Era: Experience from Community Assistance to Obtain the Right to Manage Sea Cucumbers in Sunsak Bay, East Lombok.," IOP Conf. Ser. Earth Environ. Sci., vol. 441, no. 1, (2020)

18. A. Hilmawan, M. Marsoedi, E. Susilo, and R. Rudianto, "Local Custom Values As North Lombok Coastal Area Management," Russ. J. Agric. Socio-Economic Sci., vol. 72, no. 12, pp. 307-311, (2017)

19. Sumarmi et al., "the Deep Ecology Persepective of Awig-Awig: Local Tribal Forest Preservation Laws in Tenganan Cultural Village, Indonesia," J. Sustain. Sci. Manag., vol. 15, no. 8, pp. 102-113, (2020)

20. P. Oktavia, W. Salim, and G. Perdanahardja, "Reinventing papadak/hoholok as a traditional management system of marine resources in Rote Ndao, Indonesia," Ocean Coast. Manag., vol. 161, no. April, pp. 37-49, (2018)

21. L. Zamzami, N. Effendi, Syahrizal, and Ermayanti, "Marine Resource Conservation for Sustainable food security in Indonesia," IOP Conf. Ser. Earth Environ. Sci., vol. 583, no. 1, (2020)

22. T. L. Wanadjaja and P. L. Samputra, "Examining tri hita karana as the critic to the triple bottom line of sustainable development," IOP Conf. Ser. Earth Environ. Sci., vol. 716, no. 1, p. 012121, (2021)

23. F. Ulfah, Afrizal, and A. Pratomo, "Sustainability of seahorses: Lessons learned of local wisdom from Bintan Islands, Riau Islands Province," E3S Web Conf., vol. 47, (2018)

24. F. Aulia, "Local wisdom as a determinant of the season and wind calendar for coastal communities in Jaring Halus Village," IOP Conf. Ser. Earth Environ. Sci., vol. 348, no. 1, (2019)

25. Y. P. Paulangan, K. Rumbiak, and B. Barapadang, "Fishing season and participatory mapping of the fishing ground of target fish in Depapre Bay, Jayapura Regency, Papua Indonesia," IOP Conf. Ser. Earth Environ. Sci., vol. 584, no. 1, (2020)

26. D. Oryza et al., "Duano's Local Wisdom in Preserving Marine Ecosystem at Jambi Coastal Area," IOP Conf. Ser. Earth Environ. Sci., vol. 175, no. 1, (2018)

27. A. Jati, "Environment-Wise Fishing Practice in Coastal Regions in Indonesia," E3S Web Conf., vol. 125, no. 201 9, pp. 9-11, (2019)

28. D. A. A. Sari and E. Latifah, "Revitalization of traditional fisheries rights of indigenous people in sustainable fisheries management in Indonesia," IOP Conf. Ser. Earth Environ. Sci., vol. 724, no. 1, (2021) 
29. M. A. Abdullah, S. Tripa, and T. Muttaqin, Selama Kearifan Adalah Kekayaan Eksistensi Panglima Laot dan Hukom Adat Laot di Aceh, 1st ed. Banda Aceh: Lembaga Hukom Adat Laot - Yayasan Kehati, (2006)

30. H. S. Daud, Adat Meulaot, 1st ed. Banda Aceh: Majelis Adat Aceh, (2014)

31. A. Satria, Pesisir dan Laut Untuk Rakyat, 2nd ed. Bogor: IPB Press, (2009)

32. S. Kakoty, "Ecology, sustainability and traditional wisdom," J. Clean. Prod., vol. 172, pp. 3215-3224, (2018)

33. A. Satria et al., Laut dan Masyarakat Adat. Jakarta, (2017)

34. R. K. D. Susilo, Sosiologi Lingkungan. Jakarta: PT. Raja Grafindo Perkasa, (2008)

35. D. N. Sari and wwf.id Northern Sumatera Program, "Panglima Laot Lhok Pulo Nasi : Awasi Bom Ikan, Illegal Fishing Sampai Buat Hukum Adat Laot," 2016. https://acehinsight.wwf.id/2016/02/08/panglima-laot-lhok-pulo-nasi/

36. Aceh Kini, "Diduga Pakai Bom Ikan, 8 Nelayan Aceh Ditangkap," 2020. https://kumparan.com/acehkini/diduga-pakai-bom-ikan-8-nelayan-aceh-ditangkap1teF8jm5abO/full (accessed Apr. 20, 2021).

37. Mongabay.co.id, "Pengeboman Ikan News.” https://www.mongabay.co.id/tag/pengeboman-ikan/ (accessed Apr. 20, 2021).

38. A. Satria, Pengantar Sosiologi Masyarakat Pesisir. Jakarta: Yayasan Pustaka Obor Indonesia, (2015)

39. C. M. Dichmont et al., "A generic method of engagement to elicit regional coastal management options," Ocean Coast. Manag., vol. 124, pp. 22-32, (2016)

40. A. Filous et al., "Fisheries science and marine education catalyze the renaissance of traditional management (rahui) to improve an artisanal fishery in French Polynesia," Mar. Policy, vol. 123, no. August 2020, p. 104291, (2021)

41. M. K. Vierros et al., "Considering Indigenous Peoples and local communities in governance of the global ocean commons," Mar. Policy, vol. 119, (2020)

42. L. Budiati, Good Governance Dalam Pengelolaan Lingkungan Hidup. Bandung: Ghalia Indonesia, (2012) 